\title{
Analysis of Raw Materials Components of Dry Composite Mixes for Production Food Concentrates
}

\author{
Tatyana Samuylenko \\ Department of Bakery Products Technology, Mogilev State University of Food Technologies, Mogilev 212027, Republic of Belarus
}

\begin{abstract}
Background: The simplest and most convenient food technology is the using of dry composite mixtures. They have a lot of advantages. Dry composite mixtures, which would completely be the basis for the production of personalized food concentrates, are not represented. The development of such dry composite mixtures is actual and of scientific and practical interest. The purpose of this research is the selection and justification of local import-substituting raw materials components for dry composite mixtures used as the basis for the production of food concentrates. As the objects of research, the raw materials components of the starch, fruit and vegetable, industry were selected. The work uses currently accepted standard research methods for organoleptic and physic-chemical parameters of raw materials components. The research was carried out within of the project "Theoretical Substantiation of Production Technology and the Development of Import-Substituting Food Products of Functional Purpose Based on Dry Composite Mixtures”, funded by the Belarusian Republican Foundation for Basic Research. Based on the researches, it was found out that in the composition of dry composite mixtures for the production of food concentrates it is expedient to use the following raw materials: potato starch, extruded corn starch, dried carrots, dried beets, dried topinambur and dried apples in chopped form.
\end{abstract}

Key words: Dry composite mixtures, food concentrates, raw materials components, starches, processed products of the fruit and vegetable industry.

\section{Introduction}

The main direction of the development of the food industry at the present stage is the development and provision of the population with qualitatively new food products with desired properties, allowing them to be used in both traditional and functional nutrition. Such products can both correct the arising health problems and maintain the condition of the body in the process of life.

The simplest and most convenient technology for the production of such products is the using of dry composite mixtures. Their using has some advantages compared with other technologies [1], the main of which include:

- the ability to optimize raw materials for food

Corresponding author: Tatyana Samuylenko, candidate of technical sciences, associate professor, research fields: food industry, bakery products, confectionery, food concentrates, pasta, food additives, biotechnological processes and grain products. substances, depending on the direction of the developed dry composite mixtures;

- long shelf life (6 months or more);

- a wide assortment of food products based on dry composite mixtures;

- the ability to reduce the cost of the resulting food products based on dry composite mixtures;

- simplicity and quickness of preparation food products based on dry composite mixtures;

- the ability to produce food products on the basis of dry composite mixtures, both in the conditions of large food industry enterprises and in the conditions of small producers, unspecialized enterprises (cafes, restaurants, health facilities, child-care facilities and others), as well as at home.

There are a number of dry composite mixtures in the Republic of Belarus and abroad, but when using them in an industrial environment, additional labor, energy and material costs may arise. In some instances, long preparation of raw materials or semi-finished products 
based on existing dry composite mixtures is required. Some inventions are focused on obtaining food products based on dry composite mixtures only at home. Using dry composite mixtures requires the use of dosing equipment with an accuracy exceeding the accuracy of the installed equipment at existing food enterprises. This leads to the additional using of manual labor. Applying some dry composite mixtures, additional adjustment of the existing ranges of technological parameters is required. Existing dry composite mixtures primarily are intended for the production of food products from wheat flour. In addition, they contain a significant amount of food additives. Information for the consumer about the chemical composition of the using food additives is lack. Dry composite mixtures, which would completely be the basis for the production of personalized kind of food concentrates, are not represented [2-4].

In this context, the development of such dry composite mixtures for the production of this group of food products is relevant and is of scientific and practical interest. The search for solutions in this direction will help food industry enterprises to optimize the technological process, improve the quality of manufactured food products, reduce costs associated with the storage of additional raw materials, their preparation, and energy costs.

The purpose of this research is the selection and justification of local import-substituting raw materials for dry composite mixtures used as the basis for the production of food concentrates.

\section{Methods}

As the objects of research, the raw materials of fruit and vegetable, starch industry were selected.

In the work, generally accepted standard research methods of organoleptic and physic-chemical parameters of raw materials were used [5-7].

The mass fraction of protein in the raw materials of the fruit and vegetable industry was determined by the Kjeldahl method on a Kjeltec ${ }^{\circledR} 2200$ device, the mass fraction of fiber was determined by the Kurschner-Hanek method, the mass fraction of minerals was determined by the ashing method, the active acidity was determined by the potentiometric method, the mass fraction of reducing sugars was determined by the permanganate method [5].

The studies were carried out as the part of the project "Theoretical Justification of Production Technology and the Development of Import-Substituting Functional Food Products Based on Dry Composite Mixtures”, funded by the Belarusian Republican Foundation for Basic Research [8].

\section{Results}

The possibility of using various types of starches as a raw material component of dry composite mixtures for the production of non-traditional food concentrates was investigated [9-11]. The emphasis was focused on this raw material component with the aim of the possibility of their using in the nutrition of people with disturbance of protein metabolism. Research of world experience in the production of food products with using starches showed that corn starch is most often used for this purpose. In the Republic of Belarus, potato starch is mainly produced. For this reason, a comparative analysis of potato and corn starches was carried out in quality parameters and technological characteristics. The research results are presented in Tables 1-2 and in Fig. 1.

For obtaining non-traditional food concentrates, additional stabilization of their structure is required. It can be achieved only with the using of other raw materials in a dry form, exhibiting structure-forming properties by mixing with water at a temperature of (20 $\pm 5){ }^{\circ} \mathrm{C}$. These raw materials can include modified starches. In the research used KHN (cold swelling starch) (modified starch grade C * TECH 12650, manufactured by Cargill, The Netherlands) and experimental samples KEK (corn extruded starch) and KfEK (potato extruded starch). It is known that in the process of modification of starches, their chemical 
Table 1 Quality parameters of starches.

\begin{tabular}{lll}
\hline Parameter name & Potato starch & Corn starch \\
\hline Design of product & Consistent powder & \\
\hline Colour & White with crystalline sheen & White with a yellowish tint \\
\hline Taste & Inherent to starch, off-odore & \\
\hline Moisture content, $\%$ & 17.1 & 11.2 \\
\hline Acidity, $\mathrm{cm}^{3}$ of $0.1 \mathrm{~N}$ sodium hydroxide solution & 9.8 & 19.4 \\
\hline
\end{tabular}

Table 2 Quality parameters of starch jelly of various concentrations.

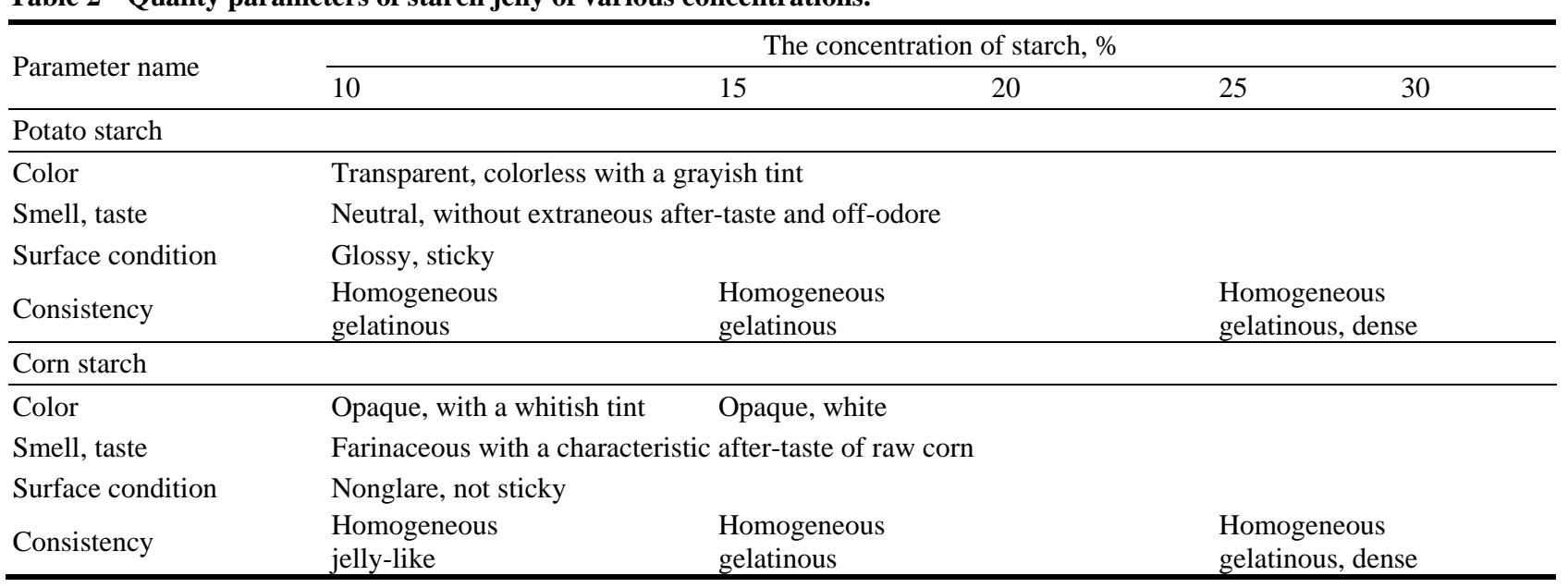

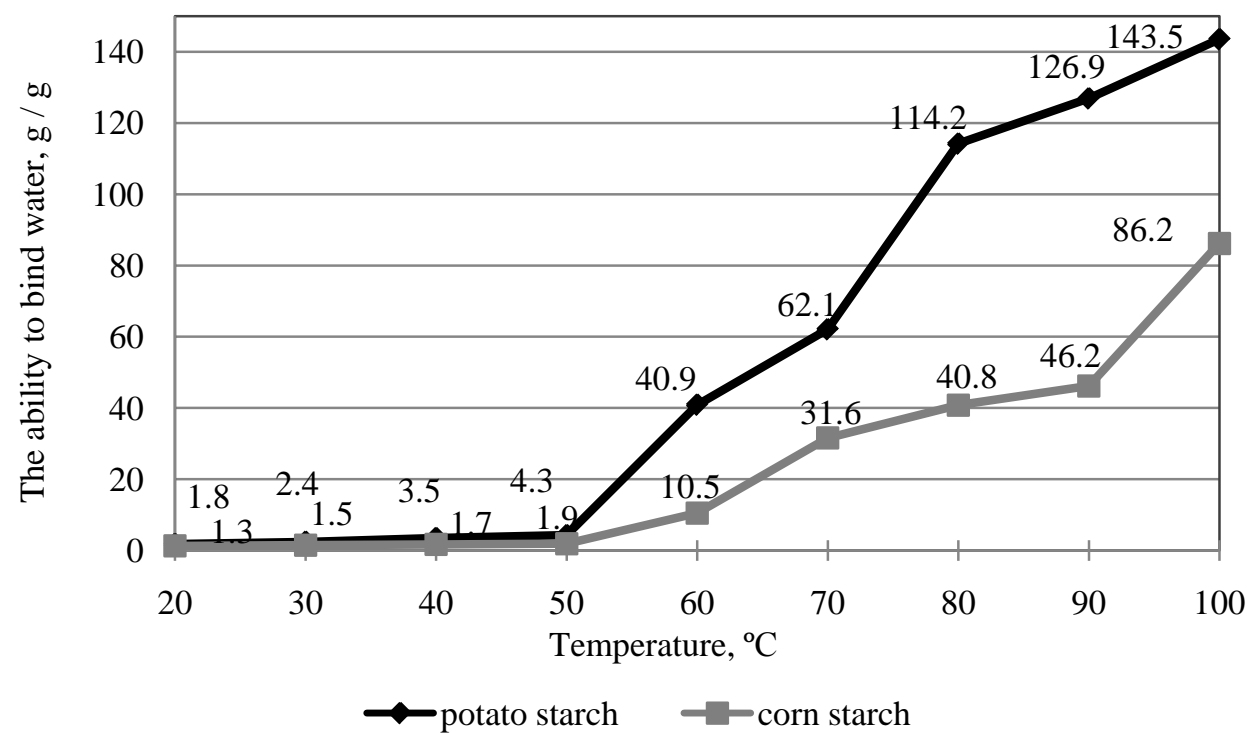

Fig. 1 The ability of starches to bind water at various temperatures.

composition or structure changes [11]. For these purposes, the research of the properties of modified starches was carried out at a temperature of $20 \pm 5^{\circ} \mathrm{C}$. The swelling and ability of modified starches to bind water at a temperature of $20 \pm 5^{\circ} \mathrm{C}$ are presented in Figs. 2 and 3.
To improve nutritional value, a wide assortment of raw materials is considered, which can be conditionally divided into two groups: obtained chemically and obtained from natural raw materials. The former is used purposefully, does not affect the energy value of the resulting food product, but requires adding of minimum 


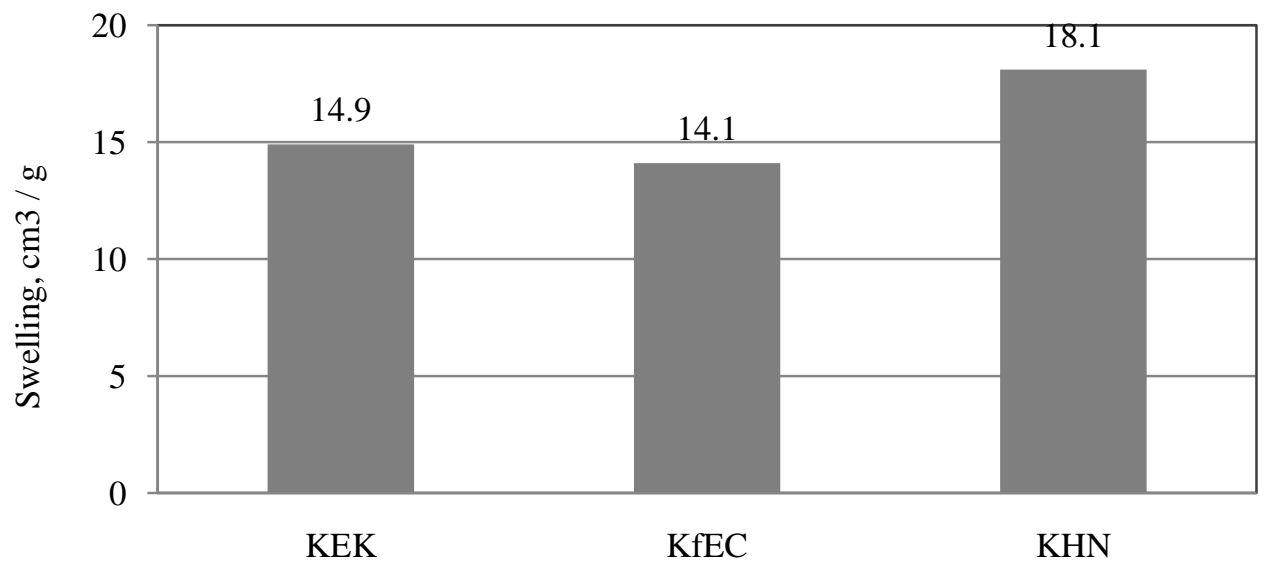

Modified Starches

Fig. 2 Swelling of modified starches.

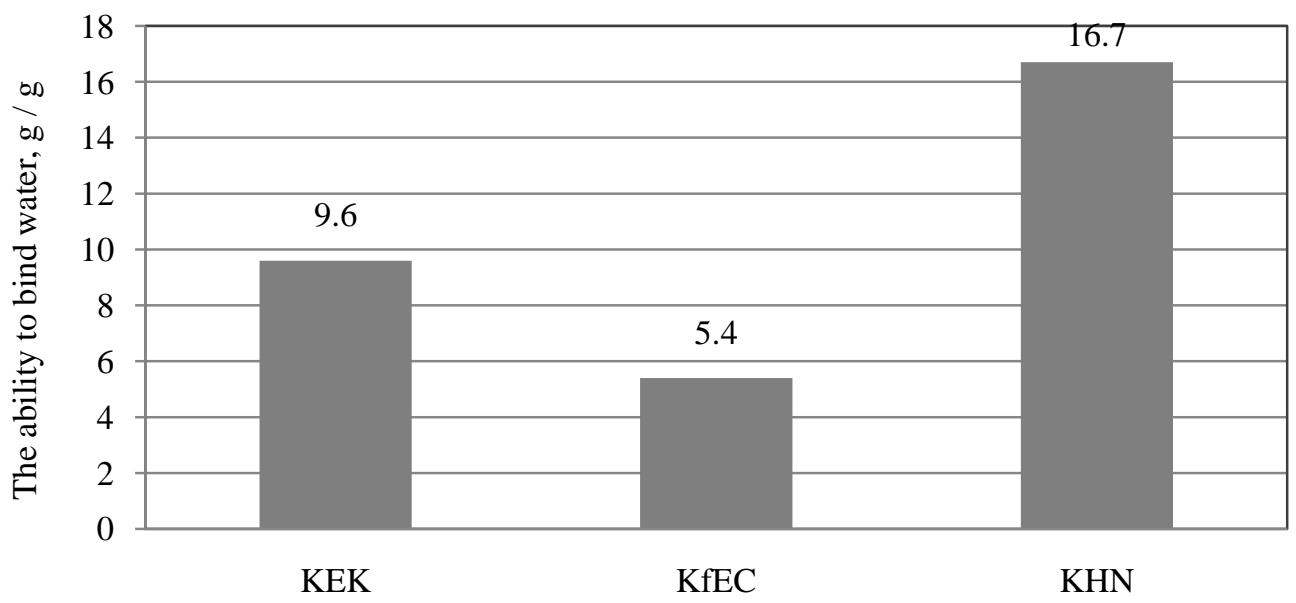

Modified Starches

Fig. 3 The ability of modified starches to bind water.

dosages, which leads to uneven distribution in the mass of the product, and is absorbed worse by the human body. The latter has a complex composition, balanced for individual substances, in the most physiologically available form, but they may contain substances that have negative effect on the course of technological process. In recent years, food consumers have increasingly preferred the second group. The using of natural raw materials is a tendency with good prospects, which allows the manufacturers not only to get the finished product with the desired functional properties, but also gives additional marketing advantages when promoting the product [12-18]. So, promising raw material components are, in particular, processed products of the fruit and vegetable industry in dried form, as a source of irreplaceable biologically active substances [19, 20].

An analysis of the activity of the fruit and vegetable industry of the Republic of Belarus showed that the using of dried carrots, dried beets, dried topinambur and dried apples in powdered form as part of dry composite mixtures for the production of food concentrates is the most economically viable [21-30]. This is due to the mass production of these raw materials and their low cost. The research results of the quality parameter of the products named above of the processing of the fruit and vegetable industry and characteristic of their chemical composition are presented in Table 3. 
Table 3 Quality parameters of products of processing of the fruit and vegetable.

\begin{tabular}{lllll}
\hline Quality parameters & Dried carrots & Dried topinambur & Dried beets & Dried apples \\
\hline Appearance & In powder form & & & \\
\hline Color & Orange & Cream-coloured & $\begin{array}{l}\text { Vinous in different } \\
\text { shades }\end{array}$ & $\begin{array}{l}\text { Yellowy-brown in } \\
\text { different shades }\end{array}$ \\
\hline Smell & Inherent without extraneous smells & & \\
\hline Taste & Inherent without extraneous smack & & $8.4 \pm 0.5$ \\
\hline Moisture content, \% & $10.4 \pm 0.5$ & $5.6 \pm 0.5$ & $3.7 \pm 0.5$ & $4.4 \pm 0.2$ \\
\hline Mass fraction of protein, \% & $5.8 \pm 0.2$ & $5.8 \pm 0.2$ & $6.5 \pm 0.2$ & $5.0 \pm 0.5$ \\
\hline Mass fraction of reducing sugars, \% & $8.0 \pm 0.5$ & $5.5 \pm 0.5$ & $4.2 \pm 0.5$ & $16.8 \pm 0.5$ \\
\hline Mass fraction of fiber, \% & $10.4 \pm 0.5$ & $8.5 \pm 0.5$ & $14.2 \pm 0.5$ & $1.6 \pm 0.5$ \\
\hline $\begin{array}{l}\text { Mass fraction of ash, \% on a dry } \\
\text { matter basis }\end{array}$ & $6.1 \pm 0.5$ & $4.6 \pm 0.5$ & $4.9 \pm 0.5$ & $2.3 \pm 0.2$ \\
\hline Active acidity, units & $5.1 \pm 0.2$ & $5.9 \pm 0.2$ & $5.8 \pm 0.2$ & \\
\hline
\end{tabular}

\section{Discussion}

The results presented in Tables 1 and 2 and in Fig. 1 allow noting the following. When starch is mixed with water at a temperature of $20 \pm 5^{\circ} \mathrm{C}$, its grains do not dissolve, but swell slowly and to a limited extent, reversibly absorbing water. This fact does not allow obtaining the bound mass necessary for the production of food products only on the basis of the presented starches. With increasing temperature, the ability of starch to bind water increases. So in the temperature range from $20^{\circ} \mathrm{C}$ to $50{ }^{\circ} \mathrm{C}$ the ability to bind water in both types of starches does not exceed $4.27 \mathrm{~g} / \mathrm{g}$ for potato starch and $1.74 \mathrm{~g} / \mathrm{g}$ for corn starch. At a temperature of $100{ }^{\circ} \mathrm{C}$, the ability to bind water in potato starch is $143.5 \mathrm{~g} / \mathrm{g}$, in corn starch-86.2 g/g. This will provide a more bound mass in the production of food products in which starch will be the main raw material component. An analysis of jelly starches showed that potato starch forms jellies with a neutral taste and smell. The obtained results allow recommending potato starch as a promising raw material component of dry composite mixtures.

The research results presented in Figs. 2 and 3 show that $\mathrm{KHN}$ is characterized the highest swelling and water-binding ability. However, an organoleptic estimation of this starch revealed the presence of an acidic taste, which is undesirable in food production. KEK and KfEK show slightly lower values of the studied parameter. In this case, KEK is characterized by slightly higher values of swelling and the ability to bind water compared to KfEK. Therefore, as a structure-forming raw material component of dry composite mixtures and the production of food products based on them, it is advisable to use KEK.

The results of the studies presented in Table 3 show that the derivative products of the fruit and vegetable industry in their composition contain a satisfactory amount of protein from $4.4 \pm 0.2 \%$ for dried apples to $6.5 \pm 0.2 \%$ for dried beets. The content of reducing sugars is the largest in dried carrots $(8.0 \pm 0.5 \%)$, the smallest in dried beets $(4.2 \pm 0.5 \%)$. Processing products of the fruit and vegetable industry contain a significant amount of fiber from $8.5 \pm 0.5 \%$ for dried topinambur to $16.8 \pm 0.5 \%$ for dried apples; mineral substances from $1.6 \pm 0.5 \%$ for dried apples to $6.1 \pm 0.5 \%$ for dried carrots. Such chemical composition allows the use of these raw materials in the composition of dry composite mixtures as functional components. In addition, dried apples have low active acidity $(2.3 \pm 0.2)$ units, which will contribute to the intensification of the technological process for the production, maintaining the optimal acidity of the resulting food products, creating a characteristic soft sour taste.

\section{Conclusion}

The substantiation of the basic, additional and functional raw materials of dry composite mixtures for 
the production of non-traditional food concentrates was carried out. The quality parameters, technological properties and characteristics of the chemical composition of raw materials were studied. The basic, raw materials that can be included in the composition of dry composite mixtures and ensure the full implementation of the technological process for the production of food products based on them, were selected.

\section{Acknowledgement}

The studies were carried out as the part of the project "Theoretical Justification of Production Technology and the Development of Import-Substituting Functional Food Products Based on Dry Composite Mixtures”, funded by the Belarusian Republican Foundation for Basic Research [8].

\section{References}

[1] Stabrovskaya, O. I., and Garifullina, O. A. 2008. “An Integrated Approach to the Development of Baking Mixtures.” Bakery in Russia 2: 17-8.

[2] Divakov, A. V., Nazarenko, E. A., and Kondratenko, R. G. 2007. "Development of Dry Composite Mixtures and Based on Them the Technology for the Production of Malt Rye Varieties of Bread." Bulletin of the Mogilev State University of Food Technologies 2: 71-7.

[3] Divakov, A. V., Nazarenko, E. A., and Baranov, O. M. 2010. "Study of the Effect of the Composition of the Dry Composite Mixture on the Flavor of Malt Rye Bread." Baker 4: 24-7.

[4] Ivanov, A. 2009. "Bread with the Addition of Grain Mixtures Is Now in Fashion.” Baker 4: 39.

[5] Vinogradova, A. A., Melkina, G. M., Fomicheva, L. A., et al. 1991. Laboratory Workshop on the General Technology of Food Production. Moscow: Agropromizdat.

[6] Richter, M. 1975. Selected Starch Research Methods. Moscow: Food Industry.

[7] Tregubov, N. N., and Kostenko, V. G. 1991. Technochemical Control of Starch and Syrup Production. M.: Agropromizdat.

[8] Samuilenko, T. D., et al. 2015. “The Theoretical Justification of Production Technology and the Development of Import-Substituting Food Products for Functional Purposes Based on Dry Composite Mixtures.” MSUFT, Mogilev.

[9] Kovalskaya, L. P. 1997. Technology of Food Production.
M.: Kolos.

[10] Grigorev, N. 2013. Food Ingredients in the Production of Bakery and Flour Confectionery Products. Moscow: DeLi Plus.

[11] Sarafanova, L. A. 2003. Nutritional Supplements: Encyclopedia. SPb: GIORD.

[12] Afanasyeva, M. P., and Solomatina, I. Y. 2002. "Modern Technologies of Flour Products for Prophylactic and Therapeutic (Dietary) Nutrition." Confectionery and Bakery Production 4: 8-9.

[13] Gulyaev, K. K. 2004. "Functional Food Products-Realities and Prospects.” Baker 6: 45-7.

[14] Polandova, R. D., and Shlelenko, L. A. 2004. “Concepts for the Development of Dietary Bakery Products for Various Regions.” Baker 4: 18-9.

[15] Spirichev, V. B., Shatnyuk, L. N., and Poznyakovsky, V. M. 2003. "Micronutrient Fortification of Foods: Scientific Approaches and Practical Solutions.” Food Industry (Russian Federation) 3: 10-6.

[16] Starovoitova, A. I., and Bazan A. I. 2003. "Functional Products.” Baker 2: 38-9.

[17] Shlelenko, L. A. 2004. “A Modern Assortment of Bakery Products for Prophylactic and Therapeutic Nutrition.” Bakery in Russia 2: 17-8.

[18] Chaldaev, P. A., and Zimichev, A. V. 2011. "Modern Directions of Fortification of Bakery Products.” Bakery in Russia 2: 24-7.

[19] Prischepov, M. A. 2008. "Antioxidants in Products from Local Plant Materials.” Food Industry (Republic of Belarus) 5: 19-20.

[20] Pochitskaya, I. M., Roslik, V. L., and Minchuk, I. M. 2009. "The Content of Natural Antioxidants in Plant Materials." Food Industry: Science and Technology 3 (5): 93-7.

[21] Bakulina, O. N., and Nekrasova, T. E. 2009. "Carotenoids: Benefiting.” Food Ingredients, Raw Materials and Additives 1: 44-6.

[22] Vasilenko, Z. V. 2006. "Dried Apple Squeezes Are a Valuable Pectin-Containing Raw Material.” Baker 5: 12-4.

[23] Vasilieva, E. A. 2007. "The Using of Additives from Topinambur to Expand the Assortment of Products." Storage and Processing of Agricultural Raw Materials 1: 51-4.

[24] Golubkina, N. A., Podobedov, V. I., Kochnev, N. K., et al. 2005. "Some Parameters of Selenium Accumulation with Girasole Topinambur Helianthus tuberosus L.” Storage and Processing of Agricultural Raw Materials 11: 38-9.

[25] Gulyaev, V. N., et al. 1984. Handbook of a Food-Concentrate and Vegetable-Drying Production. Moscow: Light and Food Industry.

[26] Davydovich, B. 2002. "Girasole Topinambur in Bakery Products.” Bakery Products 8: 22-3. 
[27] Kunitsyna, M. G. 2004. Handbook of a Technologist of Fruit and Vegetable Production. SPB: PROFI-INFORM.

[28] Perkovets, M. V. 2007. "Inulin and Oligofructose Are More Than Just Dietary Fibers and Prebiotics.” Dairy Industry 9: 55-6.
[29] Skurikhin, I. N., and Tutelyan, V. A. 2002. The Chemical Composition of Russian Food Products. Moscow: DeLi.

[30] Shepelev, A. F., and Kozhukhova, I. O. 2001. Commodity Research and Expertise of Fruits and Vegetables. Rostov-On-Don: "Mart”. 